\title{
Presence of complement-dependent cytotoxic activity against clonally-derived rat islet tumour cells in sera from Type 1 (insulin-dependent) diabetic patients and control subjects
}

\author{
D.E.Cavender*, M.A. Virji and S. Holze-Joost** \\ Department of Epidemiology, Graduate School of Public Health and Departments of Pathology and Pediatrics, University of Pittsburgh School \\ of Medicine and the Children's Hospital of Pittsburgh, Pittsburgh, Pennsylvania, USA
}

\begin{abstract}
Summary. Heat-inactivated sera from newly diagnosed Type 1 (insulin-dependent) diabetic patients and control subjects were tested for the presence of antibodies to islet cell surface antigens by means of a sensitive immunofluorescent, microcytotoxicity assay using two clones of a rat islet cell tumour as antigens. Complement-dependent cytotoxicity was found in $74 \%$ of diabetic patient sera and $87 \%$ of control sera, and there were no significant differences in titres between diabetic patients and control subjects. A minority of the sera from both patients and controls were cytotoxic for only one of the two clones, suggesting the presence of multiple antigen-antibody systems. Preadsorptions of the sera with rat liver powder,
\end{abstract}

sheep erythrocytes, and/or protein A-conjugated agarose beads were inconsistently effective in decreasing levels of lytic activity in control sera. It is concluded that more information is required concerning the antigens of rat islet cells and islet cell cytotoxic factors present in normal sera before such cells and assays can be reliably used for the detection of islet cell surface antibodies.

Key words. Type 1 diabetes, complement-dependent cytotoxicity, immunofluorescent, microcytotoxicity assay, clonal islettumour cells.
The involvement of immunologic processes in the pathogenesis of Type 1 (insulin-dependent) diabetes mellitus was first suggested by the observation that pancreatic islets from newly diagnosed Type 1 diabetic patients often contain a large number of infiltrating lymphocytes [1]. Subsequent in vitro studies demonstrated the presence of both humoral [2-4] and cellular [5,6] immunereactivity to pancreatic antigens in Type 1 diabetic patients, suggesting possible autoimmune mechanisms in this disease.

Autoantibodies to both cytoplasmic $[2,3]$ and cellsurface [4] islet cell antigens have been described, and are usually referred to as ICA and ICSA respectively. Both ICA and ICSA appear to be organ specific but not species specific $[2,7]$. However, ICA react with all four known types of hormone-producing cells in the islets [8], while ICSA are often B cell-specific $[9,10]$. In addition, ICSA-containing sera are often cytotoxic for $B$ cells in the presence of complement [11]. These observations suggest that ICA may be a nonspecific marker

\footnotetext{
Present addresses:

* Department of Internal Medicine, The University of Texas Health Science Center at Dallas, 5323 Harry Hines Blvd., Dallas, TX 75235, USA

** University Children's Clinic, Medical School, University of Göttingen, Humboltallee 38, D-3400 Göttingen, FRG
}

arising as a consequence of islet cell destruction, while ICSA may be a specific diabetogenic factor [12].

Due to the difficulty of obtaining large numbers of viable human islet cells or islets from experimental animals, several laboratories [13-15] have recently used clonal lines [16] of a X-ray-induced rat islet cell tumour [17] as a substrate for the detection of ICSA. These studies have shown that cytotoxic activity directed against the clonally derived cells can be detected in the sera of Type 1 diabetic patients. The question of specificity of the cytotoxic reaction observed has not been fully investigated and remains to be resolved if these cells are to be used extensively. In this communication, we report the results of a study of the specificity of the cytotoxicity reaction of the diabetic sera directed against these clonal cells.

\section{Subjects and methods}

\section{Patients and sera}

Since February 1979, all newly diagnosed Type 1 diabetic patients less than 17 years of age and seen at the Children's Hospital of Pittsburgh, Penn, USA have been asked to participate in an ongoing consecutive admission study of Type 1 diabetes [20]. The protocol for this study, approved by the institutional review committee, includes HLA typing 

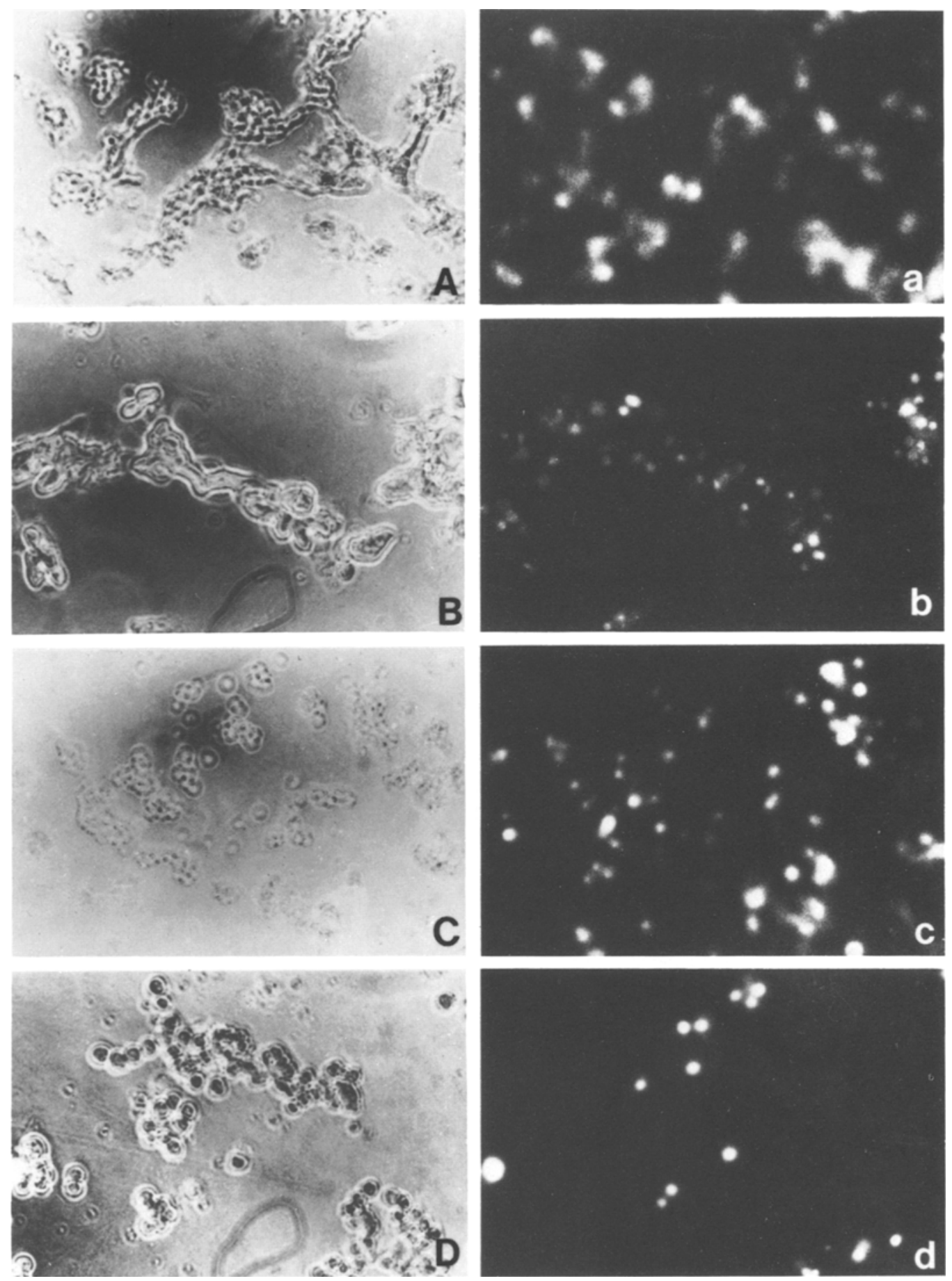

Fig. 1. A-D Immunofluorescent microcytotoxicity assay for ICSA. RIN-m5F (A, a, B, b) and $14 \mathrm{~B}(\mathrm{C}, \mathrm{c}, \mathrm{D}, \mathrm{d})$ cells grown in Terasaki plate wells were used for the complement-dependent cytotoxicity assay to detect ICSA as described in the text. The cells were photographed in situ in the wells; since the wells are conical, the plane of focus is uneven. The cells are shown under polarizing (A-D) or fluorescent (a-d) light. $A, \mathbf{a}$ and $\mathbf{C}, \mathbf{c}$ are for the same patient serum ( $\times 95$ magnification), with $90 \%$ dead cells. B, b and $\mathbf{D ,} \mathbf{d}$ are for the same control serum ( $\times 190$ magnification), with $90 \%$ and $25 \%$ dead cells respectively

and autoantibody testing as well as the collection of other genetic, immunologic and epidemiologic data. Serum samples from 39 of the most recently diagnosed patients were used in the study reported here.

Control serum samples included 19 randomly selected specimens obtained from normal non-diabetic individuals sent to our clinical laboratory for various analyses, and 5 samples from normal laboratory personnel who were not animal handlers and did not work in laboratories where animals were used. All sera were kept frozen at $-20^{\circ} \mathrm{C}$ in small aliquots until use. Just prior to testing all sera were heat-inactivated at $56^{\circ} \mathrm{C}$ for $30 \mathrm{~min}$, and were then spun for $10 \mathrm{~min}$ at $100,000 \mathrm{rpm}$ on an Airfuge ${ }^{\mathrm{TM}}$ ultracentrifuge (Beckman Instruments, Palo Alto, Calif., USA) to remove possible immune complexes.

\section{Insulinoma cells and culture}

The RIN-m5F and RIN-m14B (hereafter referred to as $5 \mathrm{~F}$ and 14B) clones [16] of a transplantable rat islet tumour [17] were kindly provided by Drs. H. Oie and A. Gazdar. The $5 \mathrm{~F}$ and $14 \mathrm{~B}$ clones secrete primarily insulin and somatostatin respectively [21]. Both lines were routinely grown in $25 \mathrm{~cm}^{2}$ tissue culture flasks (Falcon, Oxnard, Calif., USA) in RPMI 1640 medium supplemented with $10 \%$ fetal calf serum and antibiotics $(100 \mathrm{U} / \mathrm{ml}$ penicillin, $100 \mu \mathrm{g} / \mathrm{ml}$ streptomycin). The cells have a doubling time of $20 \mathrm{~h}$ (M.A. Virji and M.-J.Dimasi, unpublished observations). At the time of passage, the cells were counted, resuspended at $10^{5}$ cells $/ \mathrm{ml}$ in fresh medium and $10 \mu \mathrm{l}$ plated per 
well in Terasaki plates (Falcon, Oxnard, Calif., USA). After $48-96 \mathrm{~h}$ of incubation at $37^{\circ} \mathrm{C}$ in a humidified atmosphere of $5 \% \mathrm{CO}_{2}$ in air, the cells were washed by flooding the plate with warm culture medium, pouring off the excess and tapping the plate sharply on a paper towel. The adherent cells were used as the target antigen for the ICSA assay described below.

The $5 \mathrm{~F}$ and $14 \mathrm{~B}$ cells were used in the ICSA assays between passage numbers 32 and 49 and between passage numbers 41 and 73 respectively. The cells were periodically tested for the presence of mycoplasma and kept free of microbial contamination. The cells secreted insulin and somatostatin respectively. $5 \mathrm{~F}$ cells did not respond to glucose stimulation, but glyceraldehyde $(15 \mathrm{mmol} / \mathrm{l})$ caused a 1.5 - to 2 -fold increase in insulin release during a $1-\mathrm{h}$ stimulatory period when tested during different passage numbers. The $14 \mathrm{~B}$ cells maintained a low level of somatostatin secretion which did not change from passage to passage.

\section{Assays for islet-cell cytoplasmic antibodies (ICA) and islet cell surface antibodies (ICSA)}

ICA were detected by an immunohistochemical procedure using frozen cryostat sections of monkey pancreas, $1: 2$ dilution of serum in phosphate-buffered saline (PBS) and glucose-oxidase conjugated second antibody as described previously $[22,23]$.

ICSA were detected by a complement-dependent immunoflourescent microcytotoxicity assay as follows. Duplicate $2 \mu 1$ aliquots of doubling dilutions of sera $(1: 2,1: 4,1: 8)$ in culture medium were added to Terasaki plate wells containing washed, adherent confluent monolayers of $5 \mathrm{~F}$ or $14 \mathrm{~B}$ cells and the plates were reincubated for $30 \mathrm{~min}$ at $37^{\circ} \mathrm{C}$ in an atmosphere of $5 \% \mathrm{CO}_{2}$ in air. The plates were then washed twice as described above. Next, $5 \mu \mathrm{l}$ of an optimal dilution (1:4) of a single prescreened lot of rabbit serum as the source of complement (see below), in culture medium, were added per well and incubated for $60 \mathrm{~min}$ as described above. Two ul of a $1 \%$ solution of ethidium bromide (w/v) in PBS, pH 7.2 with 5\% EDTA (w/v) were then added, and the plates were examined by a combination of fluorescence/phase microscopy using a Leitz Dialux 20 microscope (Leitz, Wetzlar, FRG). Orange-red optics were used for the fluorescence. The percentage of dead cells was estimated as $\leqslant 10 \%$ (negative for cytotoxicity), $25 \%, 50 \% 75 \%$, or $\geqslant 90 \%$ (positive) (Fig. 1). A hyperimmune rabbit anti-rat islet cell serum, kindly donated by Dr. M.J.Dobersen [11], was used as a positive control in all experiments. This serum always killed $\geqslant 90 \%$ of both the $5 \mathrm{~F}$ and $14 \mathrm{~B}$ cells at a $1: 32$ dilution. A prescreened lot of pooled human AB sera (Medical Specialities Laboratory, Chicago, M11., USA) was used as a negative control in each assay. Its toxicity was always less than $10 \%$ in the presence of complement.

The rabbit serum as the complement source was titrated against the positive control serum and four ICSA + sera from diabetic patients in a checquerboard fashion. The rabbit serum was noncytotoxic by itself at a $1: 2$ dilution and gave equivalent cytotoxicities at $1: 2$ and $1: 4$ dilutions after incubation of the insulinoma cells with ICSA + sera at various dilutions. Therefore, a 1:4 dilution of the rabbit serum was used throughout these studies.

\section{Adsorption of sera}

To remove possible antibodies with reactivity to Forssman-like antigens or non-islet rat antigens, undiluted sera were adsorbed with various numbers of sheep erythrocytes (SRBC, Colorado Serum Company, Denver, Colo., USA) or various amounts of acetone-extracted rat liver powder (RLP, Sigma Chemical Company, St. Louis, Mo., USA), respectively, for different lengths of time and at different temperatures, as noted in the text. SRBC or RLP were then removed by centrifugation ( $500 \mathrm{~g}, 5 \mathrm{~min})$.

Adsorption of sera with protein A-conjugated agarose beads (E-Y Laboratories Inc., San Mateo, Calif., USA) was carried out at $4{ }^{\circ} \mathrm{C}$ in a cold room. Each millilitre of the suspended beads contains $2 \mathrm{mg}$ of protein A with a binding capacity of $20 \mathrm{mg}$ for human IgG. One-half $\mathrm{ml}$ of beads was withdrawn from the bottle, washed once in RPMI-
1640 , and pelleted by centrifugation $(500 \mathrm{~g}, 5 \mathrm{~min}$ ). One-half $\mathrm{ml}$ of undiluted serum was then mixed thoroughly with the pellet and incubated on ice for $5 \mathrm{~min}$. The beads were then removed by centrifugation. Immunoglobulin levels and ICSA activity in the supernatants were then compared to those in the unadsorbed sera.

In a few cases, the pelleted beads were washed three times in PBS, resuspended in $0.5 \mathrm{ml}$ of $0.2 \mathrm{~mol} / 1$ glycine-hydrochloric acid buffer ( $\mathrm{pH} 2.5$ ), and incubated on ice for $5 \mathrm{~min}$. Following a final centrifugation, the eluted material from the beads was neutralized with $15 \mathrm{ul}$ of a $7.5 \%$ sodium hydroxide solution $(w / v)$ and dialyzed against a large volume of PBS overnight in the cold room. The dialyzed material was then directly tested for ICSA as described above.

\section{Statistical analysis}

The cytotoxicity reactions of the control and diabetic sera against the tumour cells were compared by using chi-square analysis. Significance for differences between reactivity was set at $p=0.05$ or less.

\section{Results}

\section{Prevalence of ICSA in sera from Type 1 diabetic patients and control subjects}

Sera from $75 \%(29 / 39)$ of the Type 1 diabetic patients and $87 \%(21 / 24)$ of the control subjects had ICSA activity when using $>10 \%$ cell death as the definition of ICSA-positivity (Table 1 ). The data in Table 2 show that the percentages of ICSA + sera among patients and controls were not significantly different $(p>0.05)$ regardless of the percentage of cell death that was used to define a serum as positive or negative. Ultracentrifugation of the sera to remove immune complexes following heat inactivation had no effect on the results (data not shown). The majority of the positive sera for the patient and control groups had reactivity towards both the insulin-secreting $5 \mathrm{~F}$ line and the somatostatin-secreting

Table 1. ICSA activity in sera from Type 1 diabetic patients and control subjects against rat islet tumour-derived cell lines

\begin{tabular}{|c|c|c|c|c|c|}
\hline \multirow[t]{2}{*}{ Group } & \multicolumn{3}{|l|}{ Positive $^{a}$} & \multirow{2}{*}{$\begin{array}{l}\begin{array}{l}\text { Nega- } \\
\text { tive }\end{array} \\
\begin{array}{l}\text { Neither } \\
\text { line }\end{array}\end{array}$} & \multirow[t]{2}{*}{ Total } \\
\hline & $\begin{array}{l}\text { Both } \\
5 \mathrm{~F} \text { and } \\
14 \mathrm{~B}\end{array}$ & $\begin{array}{l}5 \mathrm{~F} \\
\text { only }\end{array}$ & $\begin{array}{l}14 \mathrm{~B} \\
\text { only }\end{array}$ & & \\
\hline $\begin{array}{l}\text { Type } 1 \text { diabetic } \\
\text { patients }\end{array}$ & 20 & 5 & 4 & 10 & 39 \\
\hline Control subjects & 17 & 4 & 0 & 3 & 24 \\
\hline
\end{tabular}

a $>10 \%$ cytotoxicity at $1: 2$ dilution; $5 \mathrm{~F}=\mathrm{RIN}-\mathrm{m} 5 \mathrm{~F}$ (insulin producing); $14 \mathrm{~B}=\mathrm{RIN}-\mathrm{m} 14 \mathrm{~B}$ (somatostatin producing)

Table 2. Sera positive for ICSA using different cell lysis cut-off points

\begin{tabular}{|c|c|c|c|c|}
\hline \multirow{2}{*}{$\begin{array}{l}\% \text { of cell lysis } \\
\text { used to define } \\
\text { ICSA-positivity }\end{array}$} & \multicolumn{2}{|c|}{$5 \mathrm{~F}$ cells $(\%)$} & \multicolumn{2}{|c|}{$14 \mathrm{~B}$ cells $(\%)$} \\
\hline & $\begin{array}{l}\text { Diabetic } \\
\text { patients } \\
(n=39)\end{array}$ & $\begin{array}{l}\text { Control } \\
\text { subjects } \\
(n=24)\end{array}$ & $\begin{array}{l}\text { Diabetic } \\
\text { patients } \\
(n=39)\end{array}$ & $\begin{array}{l}\text { Control } \\
\text { subjects } \\
(n=24)\end{array}$ \\
\hline$>10$ & 64 & 88 & 62 & 71 \\
\hline$>25$ & 54 & 75 & 54 & 58 \\
\hline$>50$ & 44 & 46 & 36 & 42 \\
\hline$>75$ & 23 & 38 & 23 & 29 \\
\hline
\end{tabular}


Table 3. Serum ICSA titres against $5 \mathrm{~F}$ and $14 \mathrm{~B}$ cell lines in diabetic patients and control subjects

\begin{tabular}{|c|c|c|c|c|c|c|c|}
\hline \multirow[t]{2}{*}{ Group } & \multirow{2}{*}{$\begin{array}{l}\text { No. } \\
\text { ICSA positive } \\
\text { sera tested }^{\mathfrak{a}}\end{array}$} & \multicolumn{3}{|c|}{$5 \mathrm{~F}$ cells } & \multicolumn{3}{|c|}{ 14B cells } \\
\hline & & $\leqslant 1: 2$ & $1: 4$ & $\geqslant 1: 8$ & $\leqslant 1: 2$ & $1: 4$ & $\geqslant 1: 8$ \\
\hline $\begin{array}{l}\text { Type } 1 \text { diabetic } \\
\text { patients }\end{array}$ & 26 & 11 & 4 & 11 & 16 & 5 & 5 \\
\hline Control subjects & 21 & 8 & 7 & 6 & 10 & 5 & 6 \\
\hline
\end{tabular}

a The 47 sera tested here included 26 of the 29 ICSA + sera from Type 1 diabetic patients and all 21 ICSA + sera from control subjects noted in Table 1 . Three of the 29 ICSA + diabetic patients from Table 1 did not have enough sera available to determine titres; the sera from all 3 patients killed $\geqslant 25 \%$ of both $5 \mathrm{~F}$ and $14 \mathrm{~B}$ cells at a $1: 2$ dilution

Table 4. Cytotoxic activity in adsorbed and unadsorbed control sera ${ }^{\mathrm{a}}$ for $5 \mathrm{~F}$ and $14 \mathrm{~B}$ cells

\begin{tabular}{|c|c|c|c|c|c|c|c|c|c|c|c|c|}
\hline \multirow[t]{3}{*}{ Adsorption protocol ${ }^{\mathrm{a}}$} & \multicolumn{12}{|c|}{ Serum sample } \\
\hline & \multicolumn{2}{|l|}{1} & \multicolumn{2}{|l|}{2} & \multicolumn{2}{|l|}{3} & \multicolumn{2}{|l|}{4} & \multicolumn{2}{|l|}{5} & \multicolumn{2}{|l|}{6} \\
\hline & $5 \mathrm{~F}$ & $14 B$ & $5 \mathrm{~F}$ & 14B & $5 \mathrm{~F}$ & $14 B$ & $5 \mathrm{~F}$ & 14B & $5 \mathrm{~F}$ & 14B & $5 \mathrm{~F}$ & $14 B$ \\
\hline Unadsorbed & 75 & $>90$ & 75 & 75 & $>90$ & 25 & $>90$ & 100 & 50 & 50 & 50 & 50 \\
\hline $10 \mathrm{mg} / \mathrm{ml}$ RLP $, 4^{\circ}, 16 \mathrm{~h}$ & 75 & $>90$ & 25 & 50 & $>90$ & 10 & $>90$ & 100 & 25 & 50 & 50 & 50 \\
\hline $\begin{array}{l}10 \mathrm{mg} / \mathrm{ml} \mathrm{RLP}, 37^{\circ} \\
30 \mathrm{~min} 4 \times\end{array}$ & 75 & $>90$ & 10 & 25 & 75 & 10 & $>90$ & 100 & 25 & 25 & 50 & 25 \\
\hline $\begin{array}{l}40 \mathrm{mg} / \mathrm{ml} \mathrm{RLP}, \mathrm{RT}, \\
60 \mathrm{~min}\end{array}$ & NT & NT & 25 & 50 & NT & NT & $>90$ & 100 & $<10$ & 25 & 50 & 50 \\
\hline $\begin{array}{l}5 \times 10^{8} \mathrm{SRBC} / \mathrm{ml}, 37^{\circ}, \\
30 \mathrm{~min} 4 \times\end{array}$ & NT & NT & $<10$ & 50 & NT & NT & $>90$ & 100 & $<10$ & 50 & 50 & 25 \\
\hline $\begin{array}{l}5 \times 10^{8} \mathrm{SRBC} / \mathrm{ml}, 37^{\circ} \\
30 \mathrm{~min} 2 \times+10 \mathrm{mg} / \mathrm{ml} \\
\mathrm{RLP}, 37^{\circ}, 30 \mathrm{~min} 2 \times\end{array}$ & 50 & $>90$ & NT & NT & 50 & 10 & $>90$ & 100 & NT & NT & $\mathrm{NT}$ & NT \\
\hline
\end{tabular}

a $1: 2$ dilution of serum; $\mathrm{RLP}=$ rat liver powder; $\mathrm{NT}=$ not tested; $\mathrm{SRBC}=$ sheep erythrocytes; $\mathrm{RT}=$ room temperature $; 2 \times / 4 \times=\mathrm{two} /$ four consecutive adsorptions following centrifugation

14B line. Nine of the 13 sera which killed only one of the two cell lines were cytotoxic for the $5 \mathrm{~F}$ line. Retesting of these 13 sera an average of three times each gave the same result. All five sera from normal healthy laboratory control subjects and 12 sera from the other control subjects were cytotoxic for both the cell lines.

\section{Dependence of ICSA activity on the presence of complement}

To determine whether complement activation was necessary for the cytotoxic reactions observed, two types of experiments were performed. Substitution of medium for rabbit serum in the second stage of the ICSA assay abolished all cytotoxicity. In addition, none of the sera was cytotoxic if heat-inactivated rabbit serum $\left(56^{\circ}\right.$, $30 \mathrm{~min}$ ) was used in place of untreated rabbit serum.

\section{Titres of ICSA in patient and control sera}

An artificial categorization of sera according to titre levels as low $(\leqslant 1: 2)$, intermediate $(1: 4)$ or high $(\geqslant 1: 8)$ showed that $20 \%$ to $45 \%$ of both patient and control sera had high ICSA titres against both the $5 \mathrm{~F}$ and 14B lines (Table 3). There was a greater proportion of diabetic patients than control subjects with high titres against the $5 \mathrm{~F}$ line and a lower proportion with high titres to the 14B line, but neither of these two differences was statistically significant. Though high ICSA titres

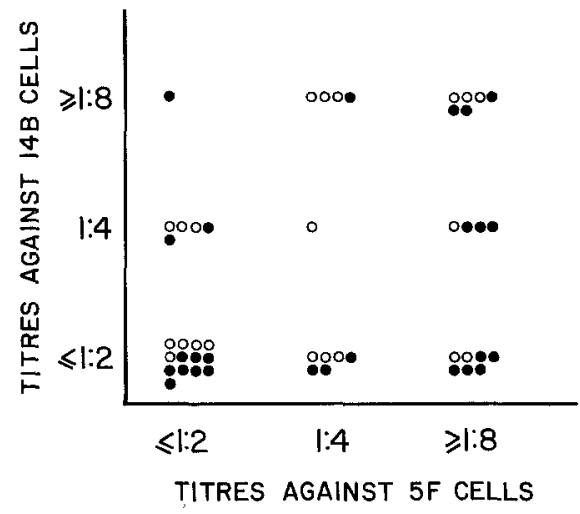

Fig. 2. Correlation of ICSA titres against $5 \mathrm{~F}$ and $14 \mathrm{~B}$ cell lines for diabetic patients $(O)$ and control subjects $(O)$. The ICSA titres were determined by the ethidium bromide immunofluorescence, microcytotoxicity assay. The sera were diluted with the culture medium RPMI 1640. The cytotoxicity for the same sera against $5 \mathrm{~F}$ and $14 \mathrm{~B}$ cells was determined in parallel assays

against both the cell lines were observed in many sera, there was almost an equal number of samples in which the titres against the two cell lines did not show a correlation (Fig. 2).

\section{Adsorption studies}

Based on previous reports $[7,11,13]$, several adsorption protocols using rat liver powder (RLP) and/or sheep erythrocytes (SRBC) were tested for their effects on 


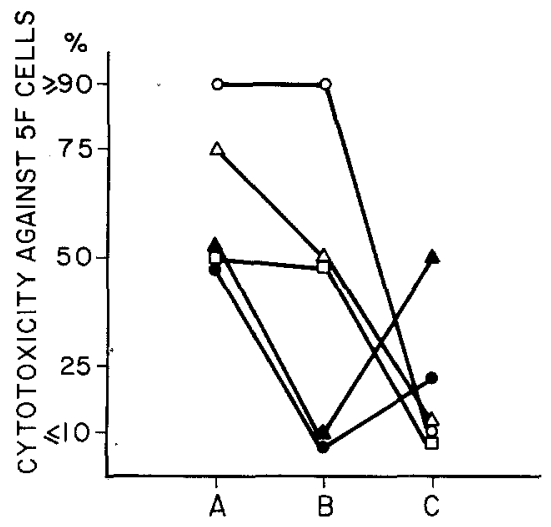

Fig.3. Effect of immunoadsorption with protein A-agarose on ICSA titres in control sera. The cytotoxicity activity in 5 control sera against $5 \mathrm{~F}$ cells was assayed by the immunofluorescence, microcytotoxicity assay, before (A) and after (B) adsorption with protein A-conjugated agarose beads; and also in the neutralized eluates $(C)$ from the beads. Four serum samples were from the diabetic patients in Table 4: Patient $4(0) ; 2(\Delta) ; 5(\square) ; 6(\Delta)$. One sample was from a patient $(\bullet)$ not shown in Table 4

ICSA activity in sera from control subjects. The results shown in Table 4 demonstrate that no adsorption procedure was consistently effective in removing (or even lowering) ICSA activity. Furthermore, in a few cases ICSA reactivity was removed for just one of the two lines. Similarly, we were unable to reduce to background levels $(\leqslant 10 \%)$ the cytotoxicity found in five ICSA + control sera by adsorption on monolayer cultures of rat embryo fibroblasts (data not shown).

Adsorption of five control sera, which showed high cytotoxic activity against $5 \mathrm{~F}$ cells, with protein A-conjugated agarose beads, gave the results shown in Figure 3. Adsorption was successful in removing ICSA from two of the five sera and the ICSA activity was recovered in the neutralized eluate from the beads. Adsorption of the other three sera with the beads had no marked effect on their ICSA levels, even though the IgG concentrations were reduced by approximately $90 \%$. Additionally, neutralized eluates from the protein A-conjugated beads used to adsorb these three sera had no demonstrable ICSA activity.

\section{Correlation between ICA and ICSA activity in patient and control sera}

Twenty-eight of the sera from 38 diabetic patients, but none of the 24 control sera, were positive for islet cell cytoplasmic antibodies (ICA) as identified by using frozen cryostat sections of monkey pancreas. There was no correlation between the presence of ICA and either the presence or titres of ICSA in the patient group (data not shown).

\section{Discussion}

The results presented here demonstrate that sera from most individuals, whether Type 1 diabetic patients or control subjects, contain cytotoxic factors for cultured rat islet tumour cells. In all cases, the cytotoxic reaction was dependent on the presence of both heat-inactivated human serum and untreated rabbit serum, suggesting that most human sera contain antibodies capable of both binding to transformed rat islet cells and fixing rabbit complement. Despite this universal dependence on rabbit serum, marked differences between the human sera were observed in other characteristics. First, ICSA activity was inconsistently removed from control sera by non-specific adsorptions with sheep erythrocytes and/or rat liver powder (Table 4). Secondly, there was a wide variation in the titres of cytotoxic activity (although diabetic patients and control subjects did not differ in this regard, Table 3). Thirdly, individual sera often had markedly different titres for the two cell lines used or sometimes were even cytotoxic for only one of the lines (Fig. 2); for example, one serum from a patient killed $50 \%$ of the $5 \mathrm{~F}$ cells at a $1: 8$ dilution but was completely negative on $14 \mathrm{~B}$ cells, even at a $1: 2$ dilution. Finally, adsorption of ICSA-positive sera with protein Aconjugated agarose beads gave variable results (Fig. 3).

Two previous studies from other laboratories have suggested that sera from Type 1 diabetic patients are significantly more cytotoxic against $5 \mathrm{~F}$ cells (as measured by a ${ }^{51} \mathrm{Cr}$ release assay) than are sera from control subjects $[13,14]$. However, their data also show that there is considerable overlap in the distributions of cytotoxic activities between sera from diabetic patients and control subjects, and that it is only in the extreme case of very marked cytotoxicity that an individual serum could be definitely classified as coming from a diabetic patient. In addition, although Eisenbarth et al. (1981) found a significant correlation between the levels of ${ }^{51} \mathrm{Cr}$ release where sera were simultaneously tested against the $5 \mathrm{~F}$ and $14 \mathrm{~B}$ clones, they also appeared to find some sera which were markedly more cytotoxic against one of the two clones [13]. It has also been reported that adsorption of ICSA positive sera with antiimmunoglobulin reagents gives variable results [13]. That these observations may not be peculiar to transformed rat islet cells only is indicated by our preliminary observations on cytotoxic activity in a smaller group of samples from control subjects and Type 1 diabetic patients ( 3 and 12 respectively) in which ${ }^{51} \mathrm{Cr}$-labeled normal rat islet cells were used as the antigen source. In the presence of rabbit complement alone, the label release was $4 \pm 1.5 \%$ (mean $\pm \mathrm{SD}, n=10$ ). However, in the presence of control sera the label release was $20.5 \pm 5.9$; for the diabetic sera, it was $37.1 \pm 6.8$ with a marked overlap between the patient and control sera. Even though the patients tended to have higher values, it was difficult to assign a cut-off point above which cytotoxic activity would definitely be indicative of the presence of autoantibodies.

Finally, it should be noted that the development of similar fluorescent, microcytotoxicity assays have been independently described in two other laboratories [25, 
26]. In the first case, normal mouse islet cells isolated by dispase treatment were used as the antigen source, while recently trypsinized $5 \mathrm{~F}$ cells were used in the other study. It was reported in both of these studies that approximately $50 \%$ of newly diagnosed Type 1 diabetic patients were ICSA + compared to almost none of the controls [25, 26]. However, a serum was considered positive in these two reports only if $50 \%$ or more of the cells were observed to take up the dye, suggesting that diabetic patients simply had higher titres of cytotoxic activity than the control subjects. This may also have had an effect on the number of patients found positive for ICSA, which was only $45 \%$, indicating the possibility of a large number of false negatives because of the high cut-off point to denote positivity of a serum sample for ICSA [26]. The high cut-off presumably was set to minimize the overlap between cytotoxicity of normal and diabetic sera. In the present study, no definite cut-off point could be established to clearly separate the diabetic patients and control subjects (Table 2). In view of our almost complete lack of knowledge concerning the nature of the relevant islet cell antigens in the etiology of Type 1 diabetes, the use of cells in ICSA assays which have been recently treated with proteases could lead to spurious results due to the possible proteolytic digestion of antigens from the cell surface. Eisenbarth et al. [13], cultured $5 \mathrm{~F}$ cells overnight following trypsin treatment, which presumably would allow for the re-expression of such antigens; the same method was used in the present study. This is of importance since trypsinization may have an effect on the surface membrane antigens, with proteolytic alterations of the membrane antigens to which control and diabetic sera may react differently and unpredictably. In a study by Toguchi et al [26], cells treated with trypsin just before analysis were used in the assay, introducing a variable with potential effect on cell membrane antigens. Additional uncontrolled variables in that study included incubations at room temperature in unbuffered medium presumably without $\mathrm{CO}_{2}$, resulting in possible effects on $\mathrm{pH}$ maintenance. In the study presented here all these factors were controlled to maintain uniformity of test conditions and assure optimal in vitro cellular environment. Also in contrast to the study of Toguchi et al. [26], the reactivities of both the unadsorbed and extensively adsorbed sera were studied in this investigation in order to understand the nature of complement dependent cytotoxicity against the tumour cells detected in the normal sera.

Our conclusion, based on these studies, is that none of the assays described to date using transformed animal islet cells adequately measures ICSA activity. This conclusion is supported by the observation of a marked overlap in ICSA activity between the diabetic patient and control sera, and from the data which show that ICSA-like activity is often not removed by adsorption with either non-islet animal tissue or anti-immunoglobulin reagents. The discrepant results using the $5 \mathrm{~F}$ and $14 \mathrm{~B}$ clones suggest the presence of multiple antigen-an- tibody systems, further complicating the interpretation of these assays. It has also been suggested that the ability of rodent islet cells to take up ${ }^{86} \mathrm{Rb}$ can be inhibited irreversibly by heterologous sera, presumably due to the activation of the alternative complement pathway [27]. Our group has previously reported that use of $5 \mathrm{~F}$ cells as antigen in an ICA assay results in an unacceptable number of both false positive and false negative reactions [22]. Until it is demonstrated that transformed rodent islet cells possess antigens similar or identical to those to which Type 1 diabetic patients react on human islet cells, and until more information is available on such heterologous systems, considerable caution is necessary when interpreting the results of experiments using animal islet tissue to identify islet cell cytotoxic activity in diabetic patients. Direct comparisons of human and normal rodent tissues for the study of islet cell-surface antigens using sera from Type 1 diabetic patients have led to the same conclusion [18, 19]. Thus, continually growing clonally-derived rat islet tumour cells, though convenient as a source of hormone-producing cells, may not be appropriate for use in detection of ICA and ICSA.

Acknowledgments. The serum samples from diabetic patients were generously provided by Dr. B. Rabin and collected at the Diabetes Research Center of the Children's Hospital of Pittsburgh. The excellent technical assistance of Ms. M.-J. Dimasi is gratefully acknowledged.

\section{References}

1. Gepts W (1965) Pathologic anatomy of the pancreas in juvenile diabetes mellitus. Diabetes 14: 619-633

2. Bottazzo GF, Florin-Chistensen F, Doniach D (1974) Islet-cell antibodies in diabetes mellitus with polyendocrine deficiencies. Lancet 2: 1279-1283

3. MacCuish AC, Barnes EW, Irvine WJ, Duncan LJ (1974) Antibodies to pancreatic islet-cells in insulin-dependent diabetic with co-existent autoimmune disease. Lancet 2: 1529-1531

4. Maclaren NK, Huang S, Fogh J (1975) Antibody to cultured human insulinoma cells in insulin-dependent diabetics. Lancet 1: 997-999

5. Neuy J, Andersen OO, Bendixen G, Egeberg J, Poulsen JE (1971) Antipancreatic cellular hypersensitivity in diabetes mellitus. Diabetes 20: 693-697

6. MacCuish AC, Jordan J, Campbell CJ, Duncan LJ, Irvin WJ (1974) Cell-mediated immunity to human pancreas in diabetes mellitus. Diabetes 23: 693-697

7. Lernmark A, Freedman ZR, Hofmann C, Rubenstein AH, Steiner DF, Jackson RL, Winter RJ, and Traisman HS (1978) Islet-cellsurface antibodies in juvenile diabetes mellitus. N Engl J Med 229: $375-380$

8. Bottazzo FF, Doniach D (1978) Islet-cell antibodies in diabetes mellitus. Evidence of an autoantigen common to all cells in the islet of Langerhans. Ric Clin Lab 8:29-38

9. Dobersen MJ, Scharff JE (1982) Preferential lysis of pancreatic Bcells by islet cell surface antibodies. Diabetes $31: 459-462$

10. Van de Winkel M, Smets G, Gepts W, Pipeleers D (1982) Islet cell surface antibodies from insulin-dependent diabetics bind specifically to pancreatic B cells. J Clin Invest 70: 41-49

11. Dobersen MJ, Scharff JE, Ginsberg-Fellner F, Notkins AL (1980) Cytotoxic autoantibodies to beta cells in the serum of patients with insulin-dependent diabetes mellitus. $\mathrm{N}$ Engl $\mathrm{J}$ Med 303: 1493-1498 
12. Lernmark A, Baekkeskov S (1981) Islet cell-antibodies-theoretical and practical implications. Diabetologia 21: 431-435

13. Eisenbarth GS, Morris MA, Scearce RM (1981) Cytotoxic antibodies to cloned rat islet cells in serum of patients with diabetes mellitus. J Clin Invest 67: 403-408

14. Rabinovitch A, MacKay P, Ludvigsson J, and Lernmark A (1984) A prospective analysis of islet-cell cytotoxic antibodies in insulindependent diabetic children. Transient effects of plasmapheresis. Diabetes 33: 224-228

15. Dyrber J, Poussier P, Nakhooda F, Marliss EB, Lernmark A (1984) Islet cell surface and lymphocyte antibodies often precede the spontaneous diabetes in the BB rat. Diabetologia 26:159-165

16. Gazdar AF, Chick WL, Oie HK, Sims HL, King DL, Weir GC, Lauris V (1980) Continuous, clonal, insulin- and somatostatin-secreting cell lines established from a transplantable rat islet cell tumor. Proc Natl Acad Sci USA 77: 3519-3523

17. Chick WL, Warren S, Chute RN, Like AA, Lauris V, Kitchen KC (1977) A transplantable insulinoma in the rat. Proc Natl Acad Sci USA 74: 628-632

18. Baekkeskov S, Nielsen JH, Marner B, Bilde J, Ludvigsson J, Lernmark A (1982) Autoantibodies in newly diagnosed diabetic children immunoprecipitate human pancreatic islet cell proteins. Nature 298: 167-169

19. Baekkeshov $S$, Lernmark A (1982) Rodent islet cell antigens recognized by antibodies in sera from diabetic patients. Acta Biol Med Germ 41: 1111-1115

20. Eberhardt M (1984) An epidemiologic perspective of the factors associated with the presentation of insulin-dependent diabetes mellitus. Dissertation. University of Pittsburgh, Pittsburgh, Pennsylvania

21. Bhathena SJ, Oie HK, Gazdar AF, Voyles NR, Wilkins SD, Recant L (1982) Insulin, glucagon, and somatostatin receptors on cultured cells and clones from rat islet cell tumor. Diabetes 31: $521-531$

22. Krell J, Rabin BS (1984) Comparison of an immunohistochemical and immunofluorescence procedure to detect antibody to pancreatic islet cells. Diabetes 33: 709-711

23. Cavender D, Rabin B, Finegold D (1984) A new sensitive immunohistochemical assay for islet cell cytoplasmic antibodies (ICA). Diabetes 33 (Suppl 1): 63 A (Abstract)

24. Dobersen MJ, Scharff JE, Notkins AL (1980) Microculture system for studying monolayers of functional $\beta$-cells. Endocrinology 160 : 1070-1073

25. Vexiau P, Deschamps I, Jansen F, Homberg JC, and Horo J (1984) Detection of islet cell antibodies by a microcytotoxicity method. $J$ Immunol Methods 68: 177-183

26. Toguchi Y, Ginsberg-Fellner F, Rubenstein $\mathbf{P}$ (1985) Cytotoxic islet cell surface antibodies (ICSA) in patients with Type I diabetes and their first degree relatives. Diabetes 34: 855-860

27. Idahl L-A, Sehlin J, Taljedal I-B, Thornell L-E (1980) Cytotoxic activation of complement by mouse pancreatic islet cells. Diabetes $29: 636-642$

Received: 7 November 1985

and in revised form: 16 July 1986

Dr. Mohamed A. Virji

Department of Pathology

University of Pittsburgh

School of Medicine

One Children's Place

Main Tower, Room 5845

Pittsburgh, PA 15213

USA 